\title{
REVERSE TRANSFER IN AUSTRALIA
}

\begin{abstract}
This article considers national Australian data on reverse transfer - the transfer of students from bachelor programs or higher to sub baccalaureate programs, institutions and sectors. It finds that previous studies have overstated the prevalence and perhaps also the significance of reverse transfer. The data are not good, but the best conclusion is that reverse transfer in Australia is from 50\% less to 50\% more than upward transfer, depending on the concept and measure of transfer used. Furthermore, the Australian survey data suggests that while most upward transfer students have completed their sub baccalaureate qualification before transferring, only just over a third of reverse transfer students have completed their degree: almost two-thirds of reverse transfer students are 'drop downs'.
\end{abstract}




\section{INTRODUCTION}

The transfer of students is usually thought of as an upward progression (Kintzer 1989) from a lower to a higher level of education. Thus, one transfers from primary to secondary to tertiary education. Similarly, within tertiary education one transfers from diploma to baccalaureate to masters to doctoral programs. In Australia, New Zealand and the United Kingdom the undergraduate bachelors or baccalaureate degree is both a terminal and a transfer qualification, to adopt United States terminology. That is, in these countries ordinary bachelor degrees prepare graduates both for a vocation and also for advanced study at honours, masters and doctoral levels. Similarly, in most Canadian provinces and in the US vocational education and training has the dual roles of not only preparing students for work, but also of preparing them for further study and transfer to baccalaureate programs. This is such an important role that the dominant understanding of student transfer in North America is from a sub baccalaureate program, institution or sector to a baccalaureate program, institution or sector (Furth 1973; Clark 1983).

A number of people have argued against considering student transfer as an upward linear process (Ignash \& Townsend 2000), as progression from 'less noble' to 'noble' (Furth 1973) institutions. Clark (1960) first identified in 1960 the transfer of students from baccalaureate to sub baccalaureate programs, what he called 'reverse-flow students' but who are now more commonly known as reverse transfer students. In 1991 the OECD (1991, p 76) noted an increase in reverse transfer in many countries, which it described as university students and graduates, mainly from academic disciplines, seeking a vocational qualification from nonuniversity institutions. Kajstura \& Keim (1992, p 39) described 2 subgroups of reverse transfer students: ' 1 ) non-completers, who attended a four-year institution, but did not complete a degree before enrolling at a two-year college; and 2) graduates, who earned at least an undergraduate degree prior to enrolling at a two-year college'. Kintzer $(1989, p 1)$ called the reverse transfer students who had not completed their higher education qualification 'drop downs'. Townsend (1999) elaborated upon different types of reverse transfer students.

Vocational education and training advocates invest considerable rhetorical significance in reverse transfer as an indicator of the limitations of universities and conversely of the strengths of vocational education and training. Some vocational education and training advocates see reverse transfer as an opportunity to redress vocational education and training's low status (Golding \& Vallence 1999, p 19). But most commentary is based on limited surveys and isolated institutional studies which have little if any application to national policy (Hagedorn \& Castro 1999, p 2; Townsend \& Dever 1999; Winter \& Harris 1999; Bryant 2001).

In Australia Golding (1995a p 38; 1995b p 30) estimated that what he called 'reverse articulation' - the transfer of students from the baccalaureate-granting sector to vocational education and training - is about 5 times more common than upward tertiary transfer. Millican (1995) supported Golding's conclusion but with a survey of only 568 students enrolled in Queensland technical and further education institutes generated from a response rate of 31\%. Werner (1998) also supported Golding in a study of 1,215 students generated from a survey of students enrolled in South Australia technical and further education institutes in 1995 with a response rate of 41\%. Doughney (now Wheelahan) (2000) argues that the data Golding used were not sufficiently robust to support the conclusions he drew, let alone the more extravagant claims of subsequent vocational education and training advocates. Golding 
\& Vallence (1999, p 9) compared the prior educational history of all vocational education and training students with the prior history of commencing rather than all higher education students, and those who commenced a bachelor level program or below rather than programs at all levels. But as can be seen from the table below, commencing students are only just over one third of all higher education students, bachelor level students are only $80 \%$ of all students, and so commencing bachelor students are only $27 \%$ of all students.

TABLE 1: COMMENCING UNDERGRADUATE STUDENTS AS A PROPORTION OF ALL UNDERGRADUATE AND ALL STUDENTS, AUSTRALIA, 1994, 1999, 2003.

\begin{tabular}{lrrr}
\hline Student type & \multicolumn{1}{c}{1994} & \multicolumn{1}{c}{1999} & \multicolumn{1}{c}{$\mathbf{2 0 0 3}$} \\
\hline Commencing undergraduates & 146,968 & 168,069 & 166,499 \\
\hline All undergraduates & 430,761 & 478,067 & 529,403 \\
\hline Commencing undergraduates as \% of all undergraduates & $34 \%$ & $35 \%$ & $31 \%$ \\
\hline Commencing postgraduates & 52,993 & 55,699 & 77,367 \\
\hline All postgraduates & 106,630 & 116,129 & 170,438 \\
\hline Commencing postgraduates as \% of all postgraduates & $50 \%$ & $48 \%$ & $45 \%$ \\
\hline Commencing undergraduates as \% of all students & $27 \%$ & $27 \%$ & $27 \%$ \\
\hline
\end{tabular}

Source: Department of Education, Science and Training $(1994,1999,2004)$ Students: selected higher education statistics, http://www.detya.gov.au/highered/statpubs.htm\#studpubs

Leaving out continuing and postgraduate students underestimates the number of higher education students with a completed technical and further education award by over 90,000 students or $400 \%$ and it underestimates the number of higher education students with some prior TAFE study by some 60,000 students or $250 \%$. Carnegie $(2000, \mathrm{p} 26)$ made the same mistake of comparing all vocational education and training students with only higher education students commencing a bachelor program or below.

This paper discusses national enrolment data on reverse student transfer in Australia and reports the rather better although still limited national survey data on reverse student transfer in Australia.

\section{AUSTRALIAN ENROLMENT DATA}

The standard publications of Australian national enrolment statistics for baccalaureategranting institutions or universities include 2 elements of data on transfer to their sector: highest prior qualification attained, and basis of admission. Extracts of these data are set out in table 2. It shows that of the domestic students commencing a bachelor level program or below 19,570 students or $11 \%$ had a TAFE award as their highest prior educational qualification in 2000 , and that this increased to 25,348 students or $13 \%$ of the intake in 2002 . A further group of students had partly completed TAFE studies. However, only $7 \%$ to $8 \%$ were admitted on the basis of a complete or incomplete TAFE program. 
TABLE 2: DOMESTIC STUDENTS COMMENCING A PROGRAM AT BACHELOR LEVEL OR BELOW WHOSE HIGHEST PRIOR QUALIFICATION ATTAINED IS A TAFE AWARD, AND DOMESTIC STUDENTS COMMENCING A PROGRAM AT BACHELOR LEVEL OR BELOW WHOSE BASIS FOR ADMISSION TO THEIR CURRENT PROGRAM IS A COMPLETE OR INCOMPLETE TAFE PROGRAM

\begin{tabular}{lcccccc}
\hline \multirow{2}{*}{ Measure } & \multicolumn{2}{c}{2000} & \multicolumn{2}{c}{2001} & \multicolumn{2}{c}{2002} \\
\cline { 2 - 7 } & $\%$ & No. & $\%$ & No. & $\%$ & No. \\
\hline Highest prior qualification is a TAFE award & $11 \%$ & 19,570 & $11 \%$ & 20,803 & $13 \%$ & 25,348 \\
\hline Basis for admission is TAFE study & $7 \%$ & 11,690 & $7 \%$ & 12,916 & $8 \%$ & 16,013 \\
\hline
\end{tabular}

Source: Department of Education, Science and Training $(2003,2002,2001)$ Students: selected higher education statistics, http://www.detya.gov.au/highered/statpubs.htm\#studpubs

This suggests that from $4 \%$ to $5 \%$ of students were admitted on the basis of a qualification other than their highest qualification, which is counter intuitive. Two explanations seem possible. It may reflect university selection officers' tendency or even bias against TAFE qualifications notwithstanding that their students consider them their highest qualification. Alternatively, it may simply reflect the poor quality of the data described by Doughney (2000), Wheelahan (2002) and Moodie (2004).

However, as Golding \& Vallence (1999, p 14), Doughney (2000) and Wheelahan (2002) argue, even were these data accurate, they would still under-report student transfer since they do not take account of the 'swirling' identified by de los Santos \& Wright (1990). A student who completed a vocational education and training qualification and a baccalaureate and who subsequently commenced another baccalaureate would correctly report their highest prior qualification as a bachelor degree, although, depending on the order in which these qualifications were completed, the student would be considered to have transferred from vocational education and training.

Only a selection of Australian higher education enrolment data is reported in the standard publications of Australian national enrolment statistics. Higher education institutions collect 3 elements that inform reverse transfer. Institutions ask students:

What education have you commenced or completed before enrolling in this program?

A post graduate program of any type?

A bachelors degree program of any type?

A diploma or associate diploma at an institution other than a TAFE college?

A diploma or associate diploma program at a TAFE college?

A TAFE award program other than the above? (Don't count secondary education, or hobby/recreational/leisure or personal enrichment programs)

Final year of secondary education at a high school, technical high school, secondary school or secondary college?

Final year of secondary education at another institution? Eg TAFE

Some other qualification or certificate of attainment which may be recognised for tertiary entrance?

No other qualification/certificate 
Institutions further ask students the year they last enrolled in the previous qualification and whether they completed it. I requested from the Department of Education, Science and Training data on domestic university students' prior TAFE study for 1994, 1999 and 2003, the latest year for which data were available at the time I made the request. Prior TAFE study was divided into 2 levels: associate degree, advanced diploma or diploma; and other TAFE award program. Most higher level TAFE qualifications are diplomas and advanced diplomas and most lower level qualifications are certificates. Results are summarised in the next table.

It will be noted first that in 2003 some 12,083 students commencing an undergraduate program had completed a TAFE diploma level program and that a further 18,024 had completed a certificate level program, giving 30,107 commencing undergraduates with a completed TAFE qualification. It will be recalled from the table above that 25,348 domestic students commencing a bachelor level program in 2002 had a TAFE qualification as their highest prior qualification. The data are from different years, but it is reasonable to estimate that of the students commencing undergraduate programs who have a TAFE qualification about $15 \%$ have a higher qualification. Or to express the same point differently, the domestic students commencing an undergraduate program with TAFE as their highest prior qualification are about $85 \%$ of all the students in the group with a prior TAFE qualification.

The proportion of commencing undergraduates with any prior TAFE study has increased from $16 \%$ in 1994 to $25 \%$ in 2003 . Interestingly, the level of prior TAFE study is not as strongly associated with commencing an undergraduate program as whether the prior TAFE study was completed. Thus students with incomplete diplomas were $3 \%$ of the undergraduate intake in 2003, the same proportion as those with incomplete certificates. However, completing a TAFE qualification doubled the likelihood of commencing an undergraduate program, irrespective of whether it was a certificate or diploma level.

It is also interesting that students with a completed certificate were a higher proportion of the undergraduate intake than students with a completed diploma. This is consistent for the 3 years for which data was obtained. There are 2 possible explanations for this, which on its face is unexpected. One possibility is that the advanced diploma and diploma is a career entry qualification: students with these qualifications do not need to undertake a degree to gain entry to their desired vocation. However, the certificate does not gain entry to as many vocations and these graduates may be more likely to upgrade their qualification, including to a degree. A second possibility is that a certificate gains transfer students entry to most undergraduate programs. Most transfer students would prefer to gain entry to their degree program as soon as possible and therefore students who can transfer after completing their certificate would not stay in TAFE to complete a diploma.

In 2003 some 5,416 students commencing a postgraduate program had completed a diploma and 6,754 had completed a certificate, giving 12,170 or $16 \%$ of students commencing a postgraduate program with a TAFE qualification. Some 14,759 or $19 \%$ of students commencing a postgraduate program had previously undertaken but not completed TAFE studies.

The proportion of domestic students with prior TAFE study commencing a postgraduate program has grown strongly from 1994, although not as strongly those commencing undergraduate programs. The other patterns observed in the undergraduate intake appear in the postgraduate intake: a low proportion of students with incomplete TAFE qualifications are admitted to postgraduate programs, and certificate holders are a higher proportion of the 
postgraduate student intake than diplomates. Note, however, that the proportion of commencing postgraduate students for whom no information on prior TAFE study was reported, which is about $8 \%$, is about the same and in some cases bigger than the cells for which data is reported. It is likely that these students had no prior study, but the high proportion of missing data nonetheless suggests that the cells with lower values should be interpreted cautiously.

TABLE 3: DOMESTIC STUDENTS COMMENCING HIGHER EDUCATION PROGRAMS WITH PRIOR TAFE STUDY BY LEVEL OF PRIOR TAFE STUDY AND WHETHER COMPLETED, FOR SELECTED YEARS

\begin{tabular}{lrrrrrr}
\hline \multirow{2}{*}{ Commencing students } & $\mathbf{1 9 9 4}$ & $\mathbf{1 9 9 9}$ & \multicolumn{2}{c}{$\mathbf{2 0 0 3}$} \\
\cline { 2 - 8 } & Enrs & \% & Enrs & \% & Enrs & \% \\
\hline Undergraduates & 146,968 & & 168,069 & & 166,499 & \\
\hline Completed diploma, etc & 5,884 & $4 \%$ & 9,218 & $5 \%$ & 12,083 & $7 \%$ \\
\hline Completed certificate, etc & 10,120 & $7 \%$ & 15,295 & $9 \%$ & 18,024 & $11 \%$ \\
\hline Incomplete diploma, etc & 5,115 & $3 \%$ & 6,527 & $4 \%$ & 5,660 & $3 \%$ \\
\hline Incomplete certificate, etc & 2,805 & $2 \%$ & 4,608 & $3 \%$ & 5,072 & $3 \%$ \\
\hline Total with prior TAFE study & 23,924 & $16 \%$ & 35,648 & $21 \%$ & 40,839 & $25 \%$ \\
\hline No information on prior TAFE study & 4,199 & $3 \%$ & 3,368 & $2 \%$ & 7,164 & $4 \%$ \\
\hline & & & & & & \\
\hline Post graduates & 52,993 & & 55,699 & & 77,367 & \\
\hline Completed diploma, etc & 1,891 & $4 \%$ & 3,306 & $6 \%$ & 5,416 & $7 \%$ \\
\hline Completed certificate, etc & 3,391 & $6 \%$ & 4,513 & $8 \%$ & 6,754 & $9 \%$ \\
\hline Incomplete diploma, etc & 810 & $2 \%$ & 1,168 & $2 \%$ & 1,523 & $2 \%$ \\
\hline Incomplete certificate, etc & 713 & $1 \%$ & 821 & $1 \%$ & 1,066 & $1 \%$ \\
\hline Total with prior TAFE study & 6,805 & $13 \%$ & 9,808 & $18 \%$ & 14,759 & $19 \%$ \\
\hline No information on prior TAFE study & 4,201 & $8 \%$ & 2,702 & $5 \%$ & 6,218 & $8 \%$ \\
\hline
\end{tabular}

Source: Khin Thin Aye, University Statistics Unit, Department of Education, Science and Training, 09 Sep 2004, source: OZUE(1989-1999) ENROL(2003) RFI No.: 04-483.

We noted in table 1 that commencing undergraduate students are $32 \%$ of all undergraduates. Therefore approximately 95,900 of all undergraduates had completed a TAFE program and 130,000 of all undergraduates had some prior TAFE study. Commencing students are $45 \%$ of all postgraduate students so about 26,900 of all postgraduates had completed a TAFE program and 32,500 students had some prior TAFE study. Thus about 122,800 university students had completed a TAFE program and a total of about 162,500 university students had some prior TAFE study.

TABLE 4: ACTUAL NUMBER OF COMMENCING DOMESTIC STUDENTS AND ESTIMATED NUMBER OF ALL DOMESTIC STUDENTS ENROLLED IN HIGHER EDUCATION PROGRAMS WITH SOME PRIOR TAFE STUDY AND THOSE WITH A COMPLETED TAFE QUALIFICATION, 1994, 1999 AND 2003

\begin{tabular}{lrrr}
\hline Student group & $\mathbf{1 9 9 4}$ & $\mathbf{1 9 9 9}$ & $\mathbf{2 0 0 3}$ \\
\hline Actual commencing undergraduates with some prior TAFE study & 23,924 & 35,648 & 40,839 \\
\hline Estimated all undergraduates with some prior TAFE study & 70,000 & 101,400 & 130,000 \\
\hline Actual commencing undergraduates with a completed TAFE qualification & 16,004 & 24,513 & 30,107 \\
\hline Estimated all undergraduates with a completed TAFE qualification & 46,900 & 70,000 & 95,900 \\
\hline Actual commencing post graduates with some prior TAFE study & 6,805 & 9,808 & 14,759 \\
\hline Estimated all postgraduates with some prior TAFE study & 13,700 & 20,500 & 32,500 \\
\hline Actual commencing postgraduates with a completed TAFE qualification & 5,282 & 7,819 & 12,170 \\
\hline Estimated all postgraduates with a completed TAFE qualification & 10,700 & 16,600 & 26,900 \\
\hline Estimated all students with some prior TAFE study & $\mathbf{8 3 , 7 0 0}$ & $\mathbf{1 2 1 , 9 0 0}$ & $\mathbf{1 6 2 , 5 0 0}$ \\
\hline Estimated all students with a completed TAFE qualification & $\mathbf{5 7 , 6 0 0}$ & $\mathbf{8 6 , 6 0 0}$ & $\mathbf{1 2 2 , 8 0 0}$ \\
\hline
\end{tabular}


This may be compared with enrolment figures for publicly funded vocational education and training. Students are asked to state on their enrolment form their highest prior educational level. Some 88,500 students enrolled in publicly funded vocational education and training programs in 2002 had a degree or postgraduate diploma as their highest prior educational level. This is 34,300 or almost $40 \%$ fewer than the estimate of 122,800 higher education students in 2003 who had a completed TAFE qualification.

TABLE 5: PUBLICLY FUNDED VOCATIONAL EDUCATION AND TRAINING STUDENTS' HIGHEST PRIOR EDUCATIONAL LEVEL

\begin{tabular}{|c|c|c|c|c|c|c|}
\hline \multirow{2}{*}{ Measure } & \multicolumn{2}{|c|}{2000} & \multicolumn{2}{|c|}{2001} & \multicolumn{2}{|c|}{2002} \\
\hline & $\%$ & No. & $\%$ & No. & $\%$ & No. \\
\hline $\begin{array}{l}\text { Students' highest prior educational level is a } \\
\text { degree or postgraduate diploma }\end{array}$ & 4.6 & 79,800 & $4.8 \%$ & 83,900 & $5.2 \%$ & 88,500 \\
\hline
\end{tabular}

Source: National Centre for Vocational Education Research $(2003,2002,2001)$ Australian Vocational Education and Training statistics: students and courses - in detail, table 11/12 students by highest prior educational level and sex; http://www.ncver.edu.au/statistic/21053.html

Pitt (2001, p 122) questioned the accuracy of the data. She compared answers on enrolment forms with enrolment histories for 100 students at a technical and further education institute. She found that, of 39 students who reported that they had completed a degree, only 11 or $28 \%$ had in fact done so. Pitt suggested that this misreporting might be caused partly by the layout and wording of the enrolment form and that these factors may affect the quality of the data for the whole sector. Its effect would be to over state the number of vocational education and training students with a completed higher education qualification.

A valuable source of data on Australian publicly funded vocational education and training is the student outcomes survey. This is a survey of a structured sample of students who completed a publicly-funded vocational education and training award or a module (subject). Table 6 shows the recent results for graduates. The apparent increase in graduates from 2001 to 2002 is probably because in 2002, for the first time module completers who were also graduates were included in the report and counted as graduates. It will be noted that in 2002 some 6,193 vocational education and training graduates had studied at a university 6 months before starting their vet program, while 13,415 - over twice as many - were attending a university for further study about 6 months after graduating from their vet program.

TABLE 6: SELECTED CHARACTERISTICS OF GRADUATES OF PUBLICLY FUNDED VOCATIONAL EDUCATION AND TRAINING PROGRAMS, 2001 AND 2002

\begin{tabular}{lrrrr}
\hline \multirow{2}{*}{ Graduates } & \multicolumn{2}{c}{$\mathbf{2 0 0 1}$} & \multicolumn{2}{c}{$\mathbf{2 0 0 2}$} \\
\cline { 2 - 5 } $\begin{array}{c}\text { Had a bachelor degree or higher before starting the } \\
\text { course }\end{array}$ & $9.3 \%$ & 12,405 & $9.2 \%$ & 21,986 \\
\hline Had studied at university 6 months before the course & $2.6 \%$ & 3,479 & $2.6 \%$ & 6,193 \\
\hline $\begin{array}{l}\text { Was attending a university for further study after } \\
\text { graduation }\end{array}$ & $8.5 \%$ & 11,444 & $8.8 \%$ & 13,415 \\
\hline $\begin{array}{l}\text { Was studying a bachelor's degree or higher after } \\
\text { graduation }\end{array}$ & $7.7 \%$ & 10,392 & $8.0 \%$ & 12,137 \\
\hline
\end{tabular}

Source: National Centre for Vocational Education Research Ltd. $(2003,2004)$ Student outcomes survey, frequency counts, http://www.ncver.edu.au/statistic/publications/1498.html 
On initial inspection table 6 suggests that upward transfer from vocational education and training is about twice reverse transfer to vocational education and training. However, it seems at least possible if not probable that the time lag between vocational education and training enrolment and subsequent higher education enrolment may be generally less than the lag between higher education enrolment and subsequent vet enrolment (Giles-Peters 2004). One may hypothesise that many students progress directly from a vocational education and training diploma to a baccalaureate program while many higher education students start a vocational education and training program after some time in the workforce or raising a family. This would be disguised by the data reported in table 6 since it reports students' origin 6 months before they started their vocational education and training program and destination about 6 months after they completed their program.

The data for vocational education and training students who completed modules or subjects (and not a whole qualification) are set out in table 7 and are similar to those for graduates in 2001. For 2002, somewhat higher proportions of module completers than graduates had a baccalaureate background.

TABLE 7: SELECTED CHARACTERISTICS OF STUDENTS WHO COMPLETED PUBLICLY FUNDED VOCATIONAL EDUCATION AND TRAINING MODULES (SUBJECTS), 2001 AND 2002

\begin{tabular}{lrrrr}
\hline \multirow{2}{*}{ Module completers } & \multicolumn{2}{c}{$\mathbf{2 0 0 1}$} & \multicolumn{2}{c}{$\mathbf{2 0 0 2}$} \\
\cline { 2 - 4 } & $\%$ & No. & \multicolumn{1}{c}{$\%$} & No. \\
\hline Had a bachelor degree or higher before starting course & $9.7 \%$ & 18,854 & $11.0 \%$ & 16,672 \\
\hline Had studied at university 6 months before course & $2.7 \%$ & 5,305 & $3.0 \%$ & 4,610 \\
\hline
\end{tabular}

Source: National Centre for Vocational Education Research Ltd. $(2003,2004)$ Student outcomes survey, frequency counts, http://www.ncver.edu.au/statistic/publications/1498.html.

Note that, while only some $5 \%$ of all vocational education and training students reported a degree or postgraduate diploma as their highest prior educational level, some $9 \%$ of vocational education and training graduates and $10 \%$ of module completers reported having a bachelor degree or higher before starting their program. The data come from different collections and so may not be comparable. But if they are comparable one may infer that students who have already completed a baccalaureate are more likely to complete their vocational education and training module or award, which would be expected.

Students entering higher education generate a much higher number of enrolments than the same number of students entering vocational education and training because higher education students undertake longer programs and thus stay in the system longer than vocational education and training students. As Giles-Peters (2004) explained to me, considering the enrolments or stocks of students in a sector with prior study from the other sector produces quite different results from considering the flows of students into each sector. This is elaborated in the next section. 


\section{STOCKS AND FLOWS}

Consider a simplified case where each year vocational education and training admits 100 students, 50 of whom have a higher education qualification. Assume that all vocational education and training students enrol for 1 year, so that at any time there are 100 vocational education and training students, 50 of whom have a higher education qualification. Also assume that each year higher education admits 100 students of whom 50 have a vocational education and training qualification, but assume that all higher education students enrol for 3 years. In the first year there would be 50 higher education students with a vocational education and training qualification. These would continue their enrolment in year 2 when another 50 students with vocational education and training qualifications are admitted, giving a total of 100 higher education students with a vocational education and training qualification. In year 3 there would be 150 higher education students with a vocational education and training qualification. By year 4 the 100 students admitted in year 1 would discontinue, giving a 'steady state' of 300 higher education students, 150 of whom have vocational education and training qualifications. This is illustrated in table 8 .

TABLE 8: SHORT PROGRAMS HAVE LESSER STOCKS OF STUDENTS THAN LONG PROGRAMS WITH THE SAME FLOW OF STUDENTS

\begin{tabular}{lcccc}
\hline & Year 1 & Year 2 & Year 3 & Year 4 \\
\cline { 2 - 5 } Number of vet admissions & 100 & 100 & 100 & 100 \\
\hline Number of vet admissions with a higher ed qual & 50 & 50 & 50 & 50 \\
\hline Number of vet students & 100 & 100 & 100 & 100 \\
\hline Number of vet students with a higher ed qual & 50 & 50 & 50 & 50 \\
\hline Percentage of vet students with a higher ed qual & $50 \%$ & $50 \%$ & $50 \%$ & $50 \%$ \\
\hline Number of higher ed admissions & 100 & 100 & 100 & 100 \\
\hline Number of higher ed admissions with a vet qual & 50 & 50 & 50 & 50 \\
\hline Number of higher ed students & 100 & 200 & 300 & 300 \\
\hline Number of higher ed students with a vet qual & 50 & 100 & 150 & 150 \\
\hline Percentage of higher ed students with a vet qual & $50 \%$ & $50 \%$ & $50 \%$ & $50 \%$ \\
\hline
\end{tabular}

This illustrates that while the flow of higher education students to vocational education and training may the same as the flow of vocational education and training students to higher education, the stock or total enrolment count of higher education students with a vocational education and training qualification is bigger than the stock of vocational education and training students with a higher education qualification by the greater duration of higher education enrolments. This is corrected if one examines percentages rather than absolute counts of total enrolments, but this disguises the volume of transfers.

Unfortunately the NCVER doesn't report highest prior educational level of students commencing a vocational education and training program. This is because the centre collects program commencements but not unduplicated student commencements. So if a student began 2 programs in a year they would be counted twice in the centre's reports (Karmel 2004). However, Giles-Peters (2004) reports from an unpublished internal report that in 2001 some 71,922 commencing vocational education and training students had previously completed higher education qualifications whereas in 2003 only 42,277 commencing higher education students had completed a technical and further education qualification, suggesting that reverse transfer is about $40 \%$ greater than upward transfer. Giles-Peters suggests that this may be at least partly because higher education has grown faster than vocational education and training recently and that therefore these rates would balance out were vocational education and training and higher education to grow at the same rate. 


\section{HOW MANY AUSTRALIAN VET STUDENTS ARE THERE?}

The discussion of Australian tertiary education student transfer so far has compared enrolment data collected in one sector with enrolment data collected by very different methods in the other sector. This makes comparisons tricky and at best approximate. No such difficulty arises with national surveys, and results from 2 national surveys will be reported here. But the national surveys raise another difficulty since the number of vocational education and training students they report is significantly different from the number reported in the enrolments collections.

The data most commonly used by analysts of Australian vocational education and training are enrolments reported by the National Centre for Vocational Education Research. The national centre collects reports of enrolments from State and Territory vocational education and training authorities which in turn collects enrolment reports from vocational education and training providers. The national centre reported that $1,224,900$ students were enrolled in a publicly funded vocational education and training program of certificate level I or higher in 2001.

A second source of data on vocational education and training participation is the national census. However, the 2001 census reports that only 493,900 people attended a technical and further education institute in 2001, only $40 \%$ of the enrolments reported by the national centre. A third source of data on vocational education and training participation in 2001 is the Australian Bureau of Statistics' survey of education, training and information technology conducted from April to August 2001. This estimated that 664,400 students were undertaking technical and further education qualifications at the time of the survey, rather more than the attendance reported in the census but still only $54 \%$ of the enrolments reported by the national centre.

While the national census and ABS survey data differ radically from national reports of enrolments in vocational education and training, they are reasonably close to national reports of enrolment in higher education. This is shown in table 9.

TABLE 9: COMPARISON OF REPORTS OF ATTENDANCE AT TAFE INSTITUTES AND UNIVERSITIES IN THE CENSUS AND IN AN ABS SURVEY AND NCVER'S AND DEST'S REPORTS OF ENROLMENTS, 2001

\begin{tabular}{lrr}
\hline Source & Tafe & University \\
\hline ABS 2001 census, catalogue no. 2001.0 & 493,924 & 722,125 \\
\hline $\begin{array}{l}\text { ABS 2001 survey of education, training and information technology, } \\
\text { cat 6278.0 }\end{array}$ & 664,400 & 859,800 \\
\hline $\begin{array}{l}\text { NCVER Australian vocational education and training statistics 2001 } \\
\text { - enrolled in AQF certificate I or higher }\end{array}$ & $1,224,900$ & \\
\hline DEST Students 2001: selected higher education statistics & & 726,418 \\
\hline
\end{tabular}

There are 6 possible explanations for these major inconsistencies in the number of vocational education and training students. First, the Australian Bureau of Statistics collects 'snapshot' data by the census date method which counts attendance at a specified point of time whereas vocational education and training collects continuous data by the turnstile method which counts enrolments throughout the whole year. Thus the 2001 census asked respondents 'Is the 
person attending a school or any other educational institution?' (question 22) and 'What type of educational institution is the person attending?' (question 23) as at the census night, 7 August 2001. This is similar to the way universities counted enrolments until 2003. It counted enrolments as at 2 reference dates (31 March and 31 August). In contrast vocational education and training counted all students who ever enrolled during 2001. Since about half of all vocational education and training students undertake relatively short programs (NCVER 2002, p 3), there could have been many people who studied in vocational education and training at some time during 2001 but not on the census night or up to the survey date for the survey of education, training and information technology. The survey of education, training and information technology asked respondents 'Are you currently enrolled in any course of study?' If they answer 'No', they are asked 'Did you enrol in any course of study at any time in 2001, that is, this year? Please exclude any course of study that you deferred this year'. The survey therefore asks whether the respondent studied at any time in the current year up to the survey date, which covers up to 7 months. It therefore finds rather higher numbers of vocational education and training students, $54 \%$ of the enrolments reported by the NCVER for the whole year. Since 7 months is $58 \%$ of the year, this seems a likely explanation for the differences in student numbers. Golding \& Vallence (1999, p 15) make the same point but reach the opposite conclusion, that vocational education and training statistics are likely to be over estimates. (Universities changed to a combination of census date and turnstile methods for counting enrolments in 2003.)

Secondly, the Australian Bureau of Statistics distinguishes between enrolment in a qualification and participation in a training course. I have tried to correct for that by considering in the table above the national centre's reports only of enrolments in Australian qualifications framework qualifications of certificate I and above, but the distinction may have led many respondents to the Australian Bureau of Statistics surveys to report a vocational education and training program as a training course and thus understate TAFE enrolments. Thirdly, many people may have taken a short program which the provider reported as vocational education and training but which the student did not identify as vocational education and training, perhaps because they considered it part of work or of a community activity.

Fourthly, Golding, Marginson \& Pascoe (1996, p 70) found that many students in their survey in 1995 and particularly students enrolled in dual sector institutions were confused by the sectoral status not only of their current program but also of their previous program. If this was the case some respondents to the ABS survey may have reported as higher education attendance what was recorded in enrolment reports as a vocational education and training enrolment. But even if 100,000 of the people who reported attending a university were enrolled in a vocational education and training program in a dual sector university, the estimated total vocational education and training attendance would still be significantly less than the national centre's enrolment report.

A fifth possible explanation is that the Australian Bureau of Statistics collected data on attendance at a technical and further education institution, whereas the NCVER collected enrolments in publicly funded vocational education and training. Within the sector TAFE is understood to be offered by a public provider whereas vocational education and training is offered by private as well as public providers and adult and community education providers, agricultural colleges, the vet operations of some universities, schools and industry skill centres (Knight \& Nestor 2000). The NCVER reports that enrolments in just technical and further education and other government institutes are $77 \%$ of all of vocational education and training enrolments, and this could explain part of the lower TAFE attendance reported in the census 
and ABS surveys. However, the distinction between TAFE and vocational education and training is not well understood outside the sector and it is not clear that it would be made by respondents. This view is supported by the director of the National Centre for Vocational Education Research (Karmel 2004).

A sixth possibility is that vocational education and training enrolment reports are inaccurate. Werner's (1998, p 27) survey of 1,544 South Australian TAFE enrolments in 1996 found that $11 \%$ of respondents said that they had not enrolled in TAFE or had not completed a higher education program contrary to the department's records. Some of the difference between departments' records and respondents' reporting of tafe enrolment was due to respondents not being aware that the programs in which they participated, typically short programs of a half to 2 days conducted in the workplace, were actually part of tafe provision (Werner 1998, p 30). However, other differences were due to misreporting by TAFE institutes, for example, by TAFE institutes reporting as enrolments people who had only applied for admission or became members of the institute's library (Werner 1998, p 28).

Vocational education and training providers are funded for the number of training hours they provide and so there is considerable financial incentive to over-report provision. Each State and Territory audits institutes' enrolment reports and Giles-Peters (2004) reports that auditors find relatively few invalid enrolments in TAFE. Harris and colleagues (2004, p 18) describes vocational education and training's national data verification procedures as 'stringent' and Giles-Peters says that while non-TAFE invalid enrolment rates are much higher they provide a much lower proportion of total vocational education and training provision and thus wouldn't affect total figures much. While this may be true, it remains possible that the audits fail to detect some over reporting of vocational education and training enrolments. The director of the National Centre for Vocational Education Research concedes that the centre's data 'have a bit of double counting' but believes that most of the discrepancies come from respondents not understanding programs and sectors in the same way as the designers of survey and enrolment forms (Karmel 2004). Universities have the same incentive to over report enrolments, but with minor exceptions, for every year's enrolment a baccalaureate student incurs a debt or tax liability of from $\$ 3,500$ to $\$ 6,000$ or a pro rata amount for a part time enrolment. Each student therefore checks their enrolment very carefully. Universities have over 700,000 auditors, so their enrolment counts are accurate.

Giles-Peters (2004) says that accounting for all these factors leaves a discrepancy of about 200,000 between the enrolment reports of the national centre for vocational education research and the survey reports of the Australian Bureau of Statistics. While this is much less than the discrepancies of 560,500 and 730,976 in the uncorrected figures shown in the table above, the remaining inconsistency in the number of vocational education and training students at least casts doubt on the results now to be considered.

\section{AUSTRALIAN BUREAU OF STATISTICS' SURVEY OF EDUCATION, TRAINING AND INFORMATION TECHNOLOGY}

The Australian Bureau of Statistics' survey of education, training and information technology was conducted over 14 weeks, from the end of April to the start of August 2001. Information was collected by personal interviews conducted by trained interviewers. The initial sample size for the survey was approximately 18,000 dwellings, from which approximately 13,200 households were selected and 12,100 (92\%) were fully responding. In total, 24,377 people responded fully to the survey (ABS 2002, p 2). 
The survey collected respondents' enrolment in a tertiary program in the current year, whether they were enrolled in a different program in the previous year, and whether they completed their previous year's program. The survey found that of the students enrolled in university in 2001 a total of 32,700 had enrolled in a different TAFE qualification in 2000. Two-thirds of these students had completed their previous TAFE qualification, which is expected from the higher education enrolment data considered earlier.

TABLE 10: STUDENTS ENROLLED IN UNIVERSITY IN 2001 WHO ENROLLED IN TAFE IN 2000 BY WHETHER COMPLETED TAFE QUALIFICATION

\begin{tabular}{lcc}
\hline & \multicolumn{2}{c}{ Enrolled in university in 2001 } \\
\cline { 2 - 3 } & Number & \% \\
\hline Completed TAFE qualification in 2000 & 20,500 & $63 \%$ \\
\hline Incomplete TAFE qualification in 2000 & 10,200 & $31 \%$ \\
\hline TOTAL & 30,700 & $100 \%$ \\
\hline
\end{tabular}

Source: Australian Bureau of Statistics Survey of Education and Training, 2001, table provided by Ms Lorraine Edmunds, National Centre for Education \& Training Statistics, Australian Bureau of Statistics ,21 September 2004.

Next we observe that of the students enrolled in TAFE in 2001 only 13,200 had enrolled in university in the previous year: that is, that direct reverse transfer is less than half that of direct upward transfer. Interestingly, almost $80 \%$ of reverse transfer students had not completed their university program.

TABLE 11: STUDENTS ENROLLED IN TAFE IN 2001 WHO ENROLLED IN UNIVERSITY IN 2000 BY WHETHER COMPLETED UNIVERSITY QUALIFICATION

\begin{tabular}{lcc}
\hline & \multicolumn{2}{c}{ Enrolled in TAFE in 2001 } \\
\cline { 2 - 3 } & Number & $\%$ \\
\hline Completed university qualification in 2000 & 2,800 & $21 \%$ \\
\hline Incomplete university qualification in 2000 & 10,400 & $79 \%$ \\
\hline TOTAL & 13,200 & $100 \%$ \\
\hline
\end{tabular}

Source: Australian Bureau of Statistics Survey of Education and Training, 2001, table provided by Ms Lorraine Edmunds, National Centre for Education \& Training Statistics, Australian Bureau of Statistics, 21 September 2004.

The survey also allows us to identify the sector of a person's most recent qualification and whether they have an earlier qualification from the other sector. As we see from the following table, the survey found that there were 104,300 persons whose most recent qualification was from TAFE but who already had a university qualification, but there were 170,400 or over $60 \%$ more people whose most recent qualification was from university but who already had a TAFE qualification.

TABLE 12: NUMBER OF PEOPLE WHO HAVE A QUALIFICATION FROM THE SECTOR OTHER THAN THAT OF THEIR MOST RECENT QUALIFICATION

\begin{tabular}{ll}
\hline TAFE is most recent qualification and has a university qualification & 104,300 \\
\hline University is most recent qualification and has a TAFE qualification & 170,400 \\
\hline
\end{tabular}

Source: Australian Bureau of Statistics Survey of Education and Training, 2001, table provided by Ms Lorraine Edmunds, National Centre for Education \& Training Statistics, Australian Bureau of Statistics, 21 September 2004. 


\section{AUSTRALIAN BUREAU OF STATISTICS' SURVEY OF EDUCATION AND WORK}

Useful information on reverse transfer is also available from the Australian Bureau of Statistics' survey of education and work. The bureau conducted its most recent survey of education and work in May 2003. It was based on a multi-stage area sample of about 30,000 private dwellings and a list sample of non-private dwellings such as hotels and motels. The survey collected data on some 44,200 persons aged 15 to 64 years. Each person in the sample is weighted by the probability of their being selected in the sample to ensure that results reflect an unbiased distribution of the population (ABS 2001).

However, we have noted that the bureau's survey reports a much lower number of people attending a TAFE institution than the NCVER enrolment reports. The ABS calculates from the results collected in its survey that 901,300 people attended a university in 2003, which is close to the 929,952 enrolments reported by the Department of Education, Science and Training. However, the ABS calculates that 577,100 people attended a TAFE institution in 2003, which is only half of the 1,155,900 enrolments in certificate I level programs or higher that the NCVER reports from its collections. Giles-Peters (2004) advises that the Australian bureau of statistics' count in the survey of education and work is about $75 \%$ of the estimated count of enrolments throughout a whole year. Even so, the ABS survey estimate of TAFE attendance is some 290,000 less than the NCVER enrolment count.

TABLE 13: COMPARISON OF ABS' SURVEY OF ATTENDANCE AT TAFE INSTITUTES AND UNIVERSITIES WITH NCVER'S AND DEST'S REPORTS OF ENROLMENTS, 2002 AND 2003

\begin{tabular}{lrr}
\hline Source & Tafe & University \\
\hline ABS (2004) Survey of education and work, 2003 & 577,100 & 901,300 \\
\hline NCVER (2003) Students and courses 2002: in detail, table 13 & $1,155,900$ & \\
\hline DEST (2004) Students 2003: selected higher education statistics & & 929,952 \\
\hline
\end{tabular}

The survey found that while 25,300 people who attended TAFE in 2002 were attending higher education in May 2003, only 15,800 who attended higher education in 2002 were attending TAFE in May 2003. That is, direct reverse transfer is $62 \%$ of direct upward transfer. This is somewhat higher than the finding from the Australian Bureau of Statistics' survey of education, training and information technology reported above that direct reverse transfer is half that of direct upward transfer.

TABLE 14: DIRECT STUDENT TRANSFER IN 2003

\begin{tabular}{ll}
\hline Attended TAFE in 2002 and higher education in May 2003 & 25,300 \\
\hline Attended higher education in 2002 and TAFE in May 2003 & 15,800 \\
\hline
\end{tabular}

Source: Australian Bureau of Statistics Survey of Education and Work, 2003, table provided by Ms Lorraine Edmunds, National Centre for Education \& Training Statistics, Australian Bureau of Statistics, 20 September, 2004.

Finally, the ABS survey of education and work asks respondents whether they completed their previous year's qualification. This is reported in the following table, in which the numbers have been rounded. While $74 \%$ of upward transfer completed their TAFE qualification $65 \%$ of reverse transfer did not complete their higher education qualification, which is consistent with previous tables. 
TABLE 15: DIRECT STUDENT TRANSFER IN 2003 BY WHETHER COMPLETED PREVIOUS QUALIFICATION

\begin{tabular}{lcc}
\hline & \multicolumn{2}{c}{ Attended higher education in May in 2003 } \\
\cline { 2 - 3 } & Number & \% \\
\hline Did not complete TAFE in 2002 & 6,600 & $26 \%$ \\
\hline Completed TAFE in 2002 & 18,700 & $74 \%$ \\
\hline Attended TAFE in 2002 & 25,300 & $100 \%$ \\
\hline & \multicolumn{2}{c}{ Attended TAFE in May 2003 } \\
\cline { 2 - 3 } & Number & \% \\
\hline Did not complete higher ed in 2002 & 10,200 & $65 \%$ \\
\hline Completed higher ed in 2002 & 5,600 & $35 \%$ \\
\hline Attended higher education in 2002 & 15,800 & $100 \%$ \\
\hline
\end{tabular}

Source: Australian Bureau of Statistics Survey of Education and Work, 2003, table provided by Mr James Ashburner, Senior Research Officer, National Centre for Education and Training Statistics, Australian Bureau of Statistics, 12 May 2004.

\section{SWIRLING, SHUFFLING AND MULTIPLE TRACKS}

Institutional studies have found that students have multiple enrolments in higher education and vocational education and training - some sequential and others concurrent. De los Santos \& Wright (1990) report that in 1989 almost 16\% of students in the Maricopa County Community College District had attended another college in the district, 3,426 were concurrently studying at Arizona State University, and 7,408 had transferred from the university. They argued that 'The movement of students should not be seen as only a straight line; progression for many can better be described as "swirling" between and among community colleges and four-year institutions on the way to a baccalaureate' (de los Santos \& Wright 1990, p 32).

In a report they call 'the community college shuffle' Maxwell and colleagues (2002, p 1) argue that 'Educational enrollment patterns can be likened to a series of playing cards. For many students the path through college is sequential, orderly and similar to a hand that progresses from deuce to ace. Other student patterns are jumbled much like a hand that results from a shuffled deck.' McCormick \& Carroll (1997) observe 'multiple tracks' enrolment and Adelman (1999, p viii) observes 'alternating or simultaneous enrollment patterns'.

Townsend (2000) reported that only $36 \%$ of her study of 614 transfer students in one state fitted the stereotypical profile of 'traditional' transfer students who progress directly from high school to a 2-year college and attend for 2 years before transferring to a 4-year college, usually with an associate's degree. Only 52\% of the transfers in the same study were upward transfers - students who moved upwards to the 4-year school by using the 2-year school as the first rung on their educational ladder - and $45 \%$ were multiple-transfer students who had attended 2 or more colleges or universities before enrolling at their current institution. Karmel \& Nguyen (2003, pp 10-11) reported that in 2001 just over 7\% of Australian vocational education and training graduates aged from 35 to 54 also had a higher education degree and that just over $11 \%$ of university graduates in the same age group also had a vet qualification, indicating extensive swirling in Australia as well as the US. 


\section{DISCUSSION}

The first and major finding of this study is that the relative size of upward and reverse transfer depends on the concept or measure of transfer used. If one examines enrolments or stocks of students, and considers students enrolled in one sector who had previously completed a qualification in the other sector, reverse transfer is about $40 \%$ less than upward transfer. The contrary findings of Golding \& Vallence (1999), Carnegie (2000) and others compare all vocational education and training students who had a higher education degree with students commencing a bachelor level program or below who had a TAFE award. This overlooks continuing students and postgraduate students with a TAFE qualification, understating the number of higher education students with a completed TAFE award by over 90,000 students or $400 \%$.

However, a different result is found if one examines the flows of students, or just commencing rather than all students who had completed a qualification in the other sector. From GilesPeters' (2004) internal unpublished report we have calculated that the flow of reverse transfer graduates is about $40 \%$ more than upward transfer graduates.

Yet other results would be given if one considered the stocks or flows of students who have previously studied in the other sector but did not complete a qualification in the other sector. We know the number of commencing higher education students with previous although incomplete TAFE study and we can make a good estimate of the total enrolment of higher education students with previous although incomplete TAFE study. Unfortunately the corresponding data for vocational education and training students are not available. However, from Australian Bureau of Statistics survey data one may conclude that the number of higher education students who subsequently enrol in vocational education and training without completing their higher education award is much higher than the number who transfer with a completed higher education award. Non graduate reverse transfer student flow is probably at least 50\% higher than non graduate upward transfer student flow, but it could higher still. This would be worth investigating further.

The Australian Bureau of Statistics' 2001 survey of education, training and information technology found that reverse transfer directly upon leaving higher education is less than half that of direct upward transfer, while the bureau's 2003 survey of education and work found that direct reverse transfer is $62 \%$ of direct upward transfer. This may be because most reverse transfer students do not transfer directly upon leaving higher education but after a delay of a year or more. Both surveys confirm the enrolment data that about three-quarters of upward transfer students complete their TAFE award while about three-quarters of reverse transfer students do not complete their higher education award. However, there is some doubt about the Australian Bureau of Statistics' data since it reports only students enrolled at TAFE institutes up to its reference date which is from one third to half the number of students reported by the NCVER as having been enrolled throughout the year.

Secondly, as other writers have observed, the metaphors of both upward and reverse transfer posit a linear progression from one program, institution or sector to another. However, institutional studies show that at least some students have studied in multiple programs, institutions or sectors, usually not following a 'pathway' defined by institutions, and sometimes with multiple enrolments concurrently. This suggests that the better metaphor is of 'swirling' (de los Santos \& Wright 1990, p 32) or 'shuffling' the deck of study options 
(Maxwell and colleagues 2002, p 1). As Golding (1995a, b), Doughney (2000) and Wheelahan (2002) observe, the national data for Australia disguises multiple enrolments.

The third finding is that the national data on tertiary education student transfer in Australia and the US isn't good enough to support many conclusions about the direction or even prevalence of student transfer. The same conclusion is reached by most studies of student transfer. For example, Osborne $(2002, \mathrm{p} 2$ ) concluded for Scotland that 'the present quantitative data on progression from FE-based HE to further HE in HEIs was limited, due to the lack of a unique identifier for students across the sector'. Some 33 US states specifically collect data on student transfers (The Education Commission of the States 2001, quoted in Wellman 2002, p 15), and many of these require institutions to report students' social security number. This not only helps to protect the integrity of the student support and reporting systems, but also allows the State to calculate accurate retention and transfer rates taking into account all transfers between institutions and sectors. It also allows the State to collect other longitudinal data on student flows more useful for planning and policy analysis than the snapshot data commonly available. Similar techniques have been recently recommended for Queensland (Gardner 2002, recommendation 8), Australian vocational education and training (ANTA 2003, p 16), New Zealand (Ministry of Education Te Tāhuhu o te Mātauranga 2001, p 8), and Scotland (Osborne 2002, p 69, Scottish Parliament enterprise and lifelong learning committee 2002, para 126).

\section{ACKNOWLEDGEMENTS}

I thank my partner Leesa Wheelahan of Griffith University for encouraging me to undertake this study and for providing valuable advice and critical comments throughout. Khin Thin Aye of the University Statistics Unit, Department of Education, Science and Training provided tables from universities' enrolment submissions. James Ashburner of the Australian Bureau of Statistics constructed and provided tables from the Survey of Education and Work, 2003. Lorraine Edmunds of the Australian Bureau of Statistics' National Centre for Education \& Training Statistics constructed and provided tables from the Survey of Education and Training, 2001 and offered several corrections to an earlier version of this paper. Dr Tom Karmel, the director of the National Centre for Vocational Education Research offered helpful comments on an earlier version of the paper. I also thank Dr Andrew R Giles-Peters of the Australian National Training Authority for his comments on an earlier version of this paper which saved it from serious mistakes and for his generous contribution of data from his unpublished internal reports. Finally, I thank 2 anonymous referees for this journal who provided extensive and constructive criticisms of an earlier version of the paper.

\section{GLOSSARY}

Baccalaureate, also bachelor and undergraduate: a program that has a minimum cumulative theoretical duration at tertiary level of three years' full-time equivalent and which normally prepares students for admission to a profession either directly or as the first stage of a postgraduate entry program; tertiary level 5A programs in UNESCO's (1997) international standard classification of education.

Delayed transfer: a student who enrols in one sector and enrols in the other sector after a gap of at least a year. 
Direct transfer: a student who enrols in one sector and enrols in the other sector in the immediately following year.

Graduate transfer: a student who enrols in one sector after completing their award in the other sector.

Non graduate transfer: a student who enrols in one sector after studying but not completing an award in the other sector.

Reverse transfer: transfer from a higher level program to a lower level program. It most commonly refers to the transfer of students from bachelor programs or higher to sub baccalaureate programs, institutions and sectors.

Swirling: the observation that students do not transfer directly from one program or sector to another, but have multiple enrolments in higher education and vocational education and training - some sequential in both directions and others concurrent.

Transfer student: a student who enrols in one tertiary education sector and subsequently enrols in the other tertiary education sector.

Upward transfer: transfer from a lower level program to a higher level program.

Gavin Moodie is principal policy adviser, Griffith University, Queensland, Australia.

\section{REFERENCES}

Adelman, C 1999, Answers in the tool box: academic integrity, attendance patterns, and bachelor's degree attainment, U.S. Department of Education, Washington, D.C.

Australian Bureau of Statistics (ABS) 2001, 'Explanatory notes' in Education and work, Australia 2001 (cat. no. 6227.0), http://www.abs.gov.au/Ausstats/abs@.nsf/0/D1363A756A115AC3CA256D7100009842 ?Open

Australian Bureau of Statistics (ABS) 2002, Basic community profile, catalogue no. 2001.0, table B11.

Australian National Training Authority (ANTA) 2003, Shaping our future: creating the national strategy for vocational education and training 2004 - 2010, a discussion starter for the next national strategy for vocational education and training 2004-2010, http://www.anta.gov.au/images/publications/National_strategy-discussion_starter.pdf.

Bryant, Alyssa 2001, 'Eric review: community college students: recent findings and trends', Community College Review, Winter 2001 v29 i3 p 77 (18).

Carnegie, Jane 2000, Pathways to partnerships, Report and draft policy guidelines, ANTA/AVCC, http://www.avcc.edu.au/students/credit\%5Ftransfer/final\%5Freport.htm.

Clark, Burton R 1960, The open door college: a case study, McGraw-Hill Book Company, New York.

Clark, Burton R 1983, The higher education system: academic organization in cross-national perspective, University of California Press, Berkeley. 
de los Santos, Alfredo G Jr \& Wright, Irene 1990, 'Maricopa's swirling students: earning one third of Arizona State's bachelor's degrees', AACJC Journal, Jun/Jul, pp 32-4.

Department of Education, Science and Training 2003, 2002, 2001, Students: selected higher education statistics, http://www.detya.gov.au/highered/statpubs.htm\#studpubs.

Doughney (now Wheelahan), Leesa 2000, 'Lifelong learning and student data collection in Australia', 9th Annual Vocational Education \& Training Research Conference, Coffs Harbour, 4 July.

Furth, Dorotea 1973, 'Short-cycle higher education: some basic considerations' in ed Dorotea Furth, Sort-cycle higher education: a search for identity, OECD, Paris, pp 13-42.

Gardner, Margaret 2002, Review in Queensland of pathways articulation through the postcompulsory years of school to further education, training and labour market participation, http://www.training.qld.gov.au/reports/gardner/index.htm.

Giles-Peters, Andrew 2004, personal communications 13, 17 \& 19 July.

Golding, Barry 1995a, 'Exploding the myth of education traffic', The Australian Tafe Teacher, first quarter (vol 29), pp 34-44.

Golding, Barry 1995b, 'Intersectional articulation and quality assurance', Journal of Tertiary Education Administration, vol 17, no 1, pp 21-39.

Golding, Barry \& Vallence, Kevin 1999, The university-VET transition, Research Centre for Vocational Education and Training, University Technology Sydney, Sydney.

Golding, Barry, Marginson, Simon \& Pascoe, Robert 1996 Changing context, moving skills: generic skills in the context of credit transfer and the recognition of prior learning, National Board of Employment, Education \& Training, Australian Government Publishing Service, Canberra, http://www.dest.gov.au/nbeet/publications/pdf/96_19.pdf

Hagedorn, L S, \& Castro, C R 1999, 'Paradoxes: California's experience with reverse transfer students', in Townsend, Barbara K (1999) Understanding the impact of reverse transfer students on community colleges: new directions for community colleges (Summer, vol 106, pp 15-26), San Francisco, Jossey-Bass.

Harris, Roger, Sumner, Robert \& Rainey, Linda (2004) Student traffic: two-way movement between vocational education and training and higher education, National Centre for Vocational Education Research, Leabrook, http://www.ncver.edu.au

Ignash, Jan M \& Townsend, Barbara 2000, Evaluating state-level articulation agreement according to good practice', Community College Review, Winter 2000 v28 i3 p1.

Kajstura, A, \& Keim, M C 1992, 'Reverse transfer students in Illinois community colleges', Community College Review, 20(2), 39-44.

Karmel, Tom 2004, personal communication 16 August. 
Karmel, Tom and Nguyen, Nhi (2003) Australia's Tertiary Education Sector. Centre for the Economics of Education and Training 7th National Conference, Melbourne

Kintzer, F C 1989, 'Articulation and transfer: a review of current literature on statewide and interinstitutional program models and trends', New Jersey State Department of Higher Education, Trenton (ERIC Document Reproduction Service No. ED 311 946), cited in Higgins \& Katsinas (1999).

Knight, Anne \& Nestor, Marianne (2000) A glossary of Australian vocational education and training terms, National Centre for Vocational Education Research, Leabrook, http://www.ncver.edu.au/research/core/cp9812.pdf

Maxwell, William, Hagedorn, Linda Serra, Brocato, Phillip, Hye Sun Moon, Perrakis, Athena 2002, 'The community college shuffle: student patterns of multiple enrolments', presented at the annual meetings of the American Educational Research Association.

McCormick, Alexander C \& Carroll, C Dennis 1997, 'Transfer behavior among beginning postsecondary students: 1989-94', National Center for Educational Statistics Statistical Analysis Report June 1997, data series: BPS:90/94, Office of Educational Research and Improvement NCES 97-266, http://nces.ed.gov/pubs97/97266.pdf

Millican, R 1995, University-TAFE articulation in Queensland, Research Report 8, Tertiary Entrance Procedures Authority, Brisbane.

Ministry of Education Te Tāhuhu o te Mātauranga 2001, Interim statement of tertiary education priorities (STEP) 2002-3, http://www.minedu.govt.nz/index.cfm?layout=document\&documentid=7366\&indexid=1 216\&indexparentid $=1028$.

Moodie, Gavin (2004) Student transfer, unpublished manuscript.

National Centre for Vocational Education Research (NCVER) (2002) Australian vocational education and training statistics 2001: in detail, http://www.ncver.edu.au/statistics/vet/ann01/id01/idall01.pdf.

Organisation for Economic Co-operation and Development (OECD) (1991) Alternatives to university, OECD, Paris.

Osborne, Mike 2002, 'Introduction', in Osborne, Mike, Gallacher, Jim \& Murphy, Mark (eds) A research review of FE/HE links - a report to the Scottish Executive Enterprise and Lifelong Learning Department, http://www.scotland.gov.uk/Resource/Doc/1043/0003992.pdf

Pitt, Heather 2001, 'Degrees go to TAFE: transition experiences in a multi-sectoral institution', 2001 conference, Australian Vocational Education and Training Research Association, NSW.

Scottish Parliament enterprise and lifelong learning committee 2002, 9th Report 2002: Final report on lifelong learning, http://www.scottish.parliament.uk/official_report/cttee/enter02/elr02-09-01.htm. 
Townsend, Barbara K 1999, Understanding the impact of reverse transfer students on community colleges: new directions for community colleges (Summer, vol 106, pp 1526), San Francisco, Jossey-Bass.

Townsend, B K \& Dever, J 1999, 'What do we know about reverse transfer students?', in ed Barbara $\mathrm{K}$ Townsend Understanding the impact of reverse transfers upon community colleges (pp. 5-14), New Directions for Community Colleges, no 106, Jossey-Bass, San Francisco.

Townsend, Barbara K 2000, 'Transfer students' institutional attendance patterns: a case study', College and University, vol 76, issue 1, pp 21-5.

United Nations Educational, Scientific and Cultural Organisation (UNESCO) (1997) International Standard Classification of Education http://www.unesco.org/education/docs/isced_1997.htm.

Wellman, Jane V 2002, 'State policy and community college-baccalaureate transfer', National Center Report \#02-6, The National centre for Public Policy and Higher Education, http://www.highereducation.org/reports/transfer/transfer.shtml.

Werner, M C 1998, Issues regarding higher education graduates in vocational education and training, National Centre for Vocational Education Research, Adelaide.

Wheelahan, Leesa 2002, 'They do things differently', Campus Review, 29 October, 2002.

Winter, Paul A \& Harris, Michael R 1999, 'Community college reverse transfer students: a field survey of a nontraditional student group', Community College Review, v 27 i1, p13. 